\title{
Obesity and Infection: Reciprocal Causality
}

\section{HAINER ${ }^{1}$, H. ZAMRAZILOVÁ ${ }^{1}$, M. KUNEŠOVÁ ${ }^{1}$, B. BENDLOVÁ ${ }^{1}$, I. ALDHOON- HAINEROVÄ ${ }^{1,2}$}

${ }^{1}$ Institute of Endocrinology, Prague, Czech Republic, ${ }^{2}$ Department of Pediatrics and Center for Research of Diabetes, Metabolism and Nutrition, Third Faculty of Medicine, Charles University, Prague, Czech Republic

Received July 13, 2015

Accepted July 27, 2015

\section{Summary}

Associations between different infectious agents and obesity have been reported in humans for over thirty years. In many cases, as in nosocomial infections, this relationship reflects the greater susceptibility of obese individuals to infection due to impaired immunity. In such cases, the infection is not related to obesity as a causal factor but represents a complication of obesity. In contrast, several infections have been suggested as potential causal factors in human obesity. However, evidence of a causal linkage to human obesity has only been provided for adenovirus 36 (Adv36). This virus activates lipogenic and proinflammatory pathways in adipose tissue, improves insulin sensitivity, lipid profile and hepatic steatosis. The E4orf1 gene of Adv36 exerts insulin senzitizing effects, but is devoid of its pro-inflammatory modalities. The development of a vaccine to prevent Adv36induced obesity or the use of E4orf1 as a ligand for novel antidiabetic drugs could open new horizons in the prophylaxis and treatment of obesity and diabetes. More experimental and clinical studies are needed to elucidate the mutual relations between infection and obesity, identify additional infectious agents causing human obesity, as well as define the conditions that predispose obese individuals to specific infections.

\section{Key words}

Obesity • Infection • Causality • Adenovirus 36 • E4orf1 protein • Impaired immunity

\section{Corresponding author}

V. Hainer, Institute of Endocrinology, Národní třída 8, 11694

Prague 1, Czech Republic. E-mail: vhainer@endo.cz

\section{Introduction}

The relationship between obesity and infection was not seriously considered until the 1980s. Since that time, however, several studies have revealed infection as an additional important factor in both the pathogenesis and health risks of obesity. Increased consumption of energy-dense food and a concomitant decrease in energy expenditure due to a sedentary lifestyle seem to be major players in the current global epidemic of obesity with its serious health and socioeconomic consequences (World Health Organization Media Centre 2015). Nevertheless, comprehensive analyses have demonstrated several alternative pathogenic factors leading to obesity (McAllister et al. 2009) including infection (Dhurandhar 2001). If the pathogenesis of obesity is partly mediated by infectious agents, we may speculate whether there is a relationship between obesity-susceptibility gene loci and particular infections. For instance, we have found variants of three genes (PCSK1, BDNF, and MC4R) to be associated with adenovirus $36(\operatorname{Adv} 36)$ seropositivity in Czech adolescents (Dušátková et al. 2015). Infection may not be entirely related to obesity as a causal factor, but may be thought of as a complication of obesity (Karlsson and Beck 2010). It has been shown that obese individuals are susceptible to several types of infection due to impaired immunity. Moreover, in obese subjects, particularly in those severely obese, the course of infectious diseases is more severe (Almond et al. 2013, Garcia et al. 2015). Infection should therefore be added to the list of health risks associated with obesity, which traditionally mainly includes cardiovascular and 
metabolic diseases, arthritis and certain cancers (Mokdad et al. 2003). Here, we review and discuss the factors involved in the reciprocal causality between infections and obesity. Various types of infections that cause obesity in animals and humans are briefly presented, with particular attention to the metabolic consequences of obesity in humans infected by adenovirus 36 (Adv36). It is apparent that more knowledge on associations between infection and obesity could contribute to novel diagnostic and therapeutic approaches in clinical practice.

\section{Infection as a cause of obesity}

\section{Infection-induced obesity in animals}

Several infectious agents have been identified that cause obesity in animals (Dhurandhar et al. 2001). Experimental research on the role of infection in the pathogenesis of obesity began in 1982, when Lyons et al. (1982) showed that Canine distemper virus (CDV) caused obesity in mice. CDV infected mice exhibited encephalitis with a subsequent development of obesity. Infected animals also presented with leptin resistance as a consequence of the downregulation of the leptin receptor (Bernard et al. 1999). In addition, lower levels of circulating catecholamines were described in animals with CDV infection. Subsequent studies conducted in CDV-infected mice demonstrated the decreased expression of several hypothalamic neuropeptides in the acute stage of infection (Griffond et al. 2004), and the neuropeptidergic system remained disturbed in animals exhibiting the obese phenotype. Though CDV is a virus antigenically related to measles, to date there has not been any relevant data showing an association of obesity with measles in humans. Rous-associated virus-7 (RAV-7), an avian retrovirus, leads to obesity, hyperlipidemia, hyperuricemia, fatty liver and growth failure in chickens (Carter et al. 1983). Borna disease virus (BDV) causes neuronal degeneration of brain structures and obesity in rats that is accompanied by lymphocyte infiltration of the hypothalamus, pancreatic islet hyperplasia, hyperglycemia and hypertriglyceridemia (Gosztonyi and Ludwig 1995).

Prions induce obesity in mice and hamsters (Kim et al. 1987, Carp et al. 1990). Interestingly, however, adrenalectomy can prevent the development of obesity after inoculation of these infectious agents (Kim et al. 1988), leading to the suggestion that this prion-induced obesity is due to dysregulation of the hypothalamicpituitary-adrenal axis (Kim et al. 1988). The prion-related
Creutzfeldt-Jacob disease in humans leads to bovine spongiform encephalopathy in cattle and macaques. Oral infection of macaques with prions was also shown to cause subsequent rapid weight gain within 1.5 years post infection (Strom et al. 2014). In that study, prion accumulation was confined to the gastrointestinal tract and was associated with a change in the density of intestinal glucagon-like peptide-1 (GLP-1) cells. As GLP-1 is an intestinal hormone that possesses the ability to suppress appetite and influence blood glucose homeostasis (Field et al. 2010), derangement of its secretory capacity after prion ingestion may contribute to the development of obesity. Inoculation of avian adenovirus SMAM-1 in chickens also induces obesity, with increased visceral fat and fatty liver but a paradoxical decrease in serum lipids (Dhurandhar et al. 1990, 1992).

Human adenovirus 36 induces obesity and decreases serum lipids in animals

Human Adv36 was first isolated in 1980 from the stool of a diabetic girl who suffered from enteritis (Wigand et al. 1980). Human Adv36 can induce obesity in chickens, mice and monkeys (Dhurandhar et al. 2000, 2002), with infected mice showing a prevalence of obesity 2.7 times higher than in control animals. Transmission of Adv36 was demonstrated from infected individuals to non-infected animals housed in the same cage, as well as after intranasal inoculation of the blood of infected chickens (Dhurandhar et al. 2001), and viral deoxyribonucleic acid (DNA) persisted in the blood of infected chickens for up to 25 days. Similarly to infection with the SMAM-1 virus, animals infected with Adv36 paradoxically exhibited lower serum levels of cholesterol and triglycerides. Adv36 DNA was detected in adipose tissue but not in the skeletal muscles, brain or hypothalamus of infected animals (Dhurandhar et al. 2000). From these studies it became apparent that the primary target for Adv36 activity is adipose tissue. Several studies have been conducted in primates such as the rhesus macaque and marmoset monkeys (Dhurandhar et al. 2002). An experiment with macaques that received a precisely-defined diet showed that the spontaneous prevalence of antibodies to Adv36 was associated with a significant weight increase and a significant decrease in total serum cholesterol concentration. Intranasal administration of Adv36 in marmosets induced positive titers of neutralizing antibodies in two thirds of infected subjects 10 weeks after virus inoculation. During the 
28 weeks of follow-up, individuals with positive Adv36 antibodies exhibited a significant increase in body weight and fat mass together with a significant reduction in serum cholesterol levels compared to the control group. Dhurandhar et al. (2014) recently demonstrated that natural infection of human Adv36 in rhesus monkeys is associated with a reduction in fasting blood glucose.

\section{Infection and obesity in humans}

Several studies have shown that individuals seropositive for Helicobacter pylori and Chlamydia pneumoniae are characterized not only by higher age and lower socioeconomic status, but also by higher BMI and higher fasting insulin concentrations (Ekesbo et al. 2000). An association of human chlamydial infections with body mass index (BMI), particle size of low-density lipoprotein (LDL), insulinemia (Dart et al. 2002) and body fat was described by Jaworowska and Bazylak (2011). International epidemiological studies have shown that the risk of being overweight (BMI $>25 \mathrm{~kg} / \mathrm{m}^{2}$ ) is significantly elevated in the presence of IgG antibodies to Chlamydia pneumoniae (OR: 1.39) and Helicobacter pylori (OR: 1.86). The simultaneous presence of antibodies against both of these bacteria synergistically further increases the risk of being overweight (OR: 2.54) (Thjodleifsson et al. 2008). A recently published large cross-sectional study from northern Finland covering 5,044 individuals also confirmed the association of IgG antibodies against Chlamydia pneumoniae with BMI. Moreover, in women these antibodies were related to waist circumference and hip circumference (Lajunen et al. 2011). However, no experimental studies have yet demonstrated a direct effect of Chlamydia pneumoniae and H. pylori on body fat accumulation. The role of these infections thus remains speculative. Associations of bacterial infections with increased BMI may rather reflect a greater susceptibility of obese individuals to these infections.

On the other hand, it has clearly been documented that some adenoviruses may play a causal role in the pathogenesis of obesity not only in animals but also in humans. Polymerase chain reaction (PCR) detected 54 types of human adenoviruses (Bil-Lula et al. 2012). In most cases, human adenoviruses cause very mild infections of the respiratory and gastrointestinal tracts. Only three human adenoviruses, Adv36, Adv37, and Adv5 have been found to have a causal relationship to obesity while acting directly on adipocytes (Atkinson 2007). As mentioned above, a subject infected with
Adv36 was described in 1980 (Wigand et al. 1980), and subjects infected with Adv37 were described in 1981 exhibiting keratoconjunctivitis, urinary and genital tract infections (de Jong et al. 1981).

The first description of obesity due to Adv infection in humans is from 1997, when infection with the avian adenovirus SMAM-1 was associated with the development of obesity (Dhurandhar et al. 1997). Individuals with positive SMAM-1 antibodies showed a significantly higher average body weight $(95.1 \mathrm{~kg}$ vs. $80.1 \mathrm{~kg}, \mathrm{p}<0.02)$ and BMI $\left(35.3 \mathrm{~kg} / \mathrm{m}^{2}\right.$ vs. $30.7 \mathrm{~kg} / \mathrm{m}^{2}$, $\mathrm{p}<0.001)$ compared to SMAM-1 antibody-negative individuals. Similarly to chickens, infected humans with SMAM-1 demonstrated significantly lower serum concentrations of cholesterol and triglycerides. Inoculation of serum samples from subjects positive for SMAM-1 antibodies into chicken embryos led to macroscopic lesions characteristic for SMAM-1 infection, whereas inoculation of serum from SMAM-1 negative subjects did not produce such lesions (Dhurandhar et al. 1997). Additional evidence supporting the association of virus infections with human obesity is discussed below. No associations with BMI have yet been demonstrated in persons who are positive for antibodies against Adv2, Adv31 and Adv37 (Atkinson et al. 2005). The potential role of Adv5 in childhood obesity has recently been raised, as seropositivity for Adv5 antibodies has been shown to be significantly more prevalent in obese than in non-obese children $-28.3 \%$ vs. $6.6 \%$ (Cakmakliogullari et al. 2014). This study was conducted in a small cohort of 120 subjects and its results should be confirmed in further studies performed in larger cohorts of both children and adults. The adipogenic potential of Adv5 has previously been shown in Adv5inoculated mice (So et al. 2005).

\section{Adenovirus 36 seropositivity and its relation to obesity}

Several studies have shown an increased prevalence of Adv36 seropositivity in obese compared to non-obese subjects ( $\mathrm{Na}$ et al. 2010, 2012, Trovato et al. 2009, 2010, Atkinson et al. 2005, 2010, Gabbert et al. 2010). A recent meta-analysis involving 5,739 subjects clearly confirmed the association of Adv36 infection with obesity (Shang et al. 2014).

Adv36 infection is usually determined by titers of antibodies against the virus. The serum neutralization assay is the gold standard to specifically detect neutralizing antibodies to Adv36, and shows no crossreactivity with other human adenoviruses such as Adv2, 
Adv31 and Adv37; however, this assay is time demanding and requires considerable training to interpret the results (Dubuisson et al. 2015). An alternative enzyme-immunoassay, which provides a quicker measurement, is not specific in detecting antibodies to Adv36 (Dubuisson et al. 2015). Since Adv36 DNA can be isolated from human fat cells (Pasarica et al. 2008), another approach for demonstrating an infection with Adv36 is to determine the presence of Adv36 DNA in adipose tissue. In humans, however, viral DNA can be analyzed only in adipose tissue samples of appropriate size obtained during surgery procedures.

Up to $30 \%$ of adult obese Americans have been found to be positive for antibodies to Adv36, compared to $11 \%$ in normal weight counterparts $(\mathrm{p}<0.001)$, and infected subjects had a BMI of about 9 units higher than uninfected individuals (Atkinson et al. 2005). Similarly to in animals, total cholesterol and triglyceride levels were significantly lower in Adv36 antibody-positive subjects. A later meta-analysis that included 10 crosssectional studies with 2,870 subjects confirmed the association of Adv36 infection with obesity and the accumulation of subcutaneous fat, but not with waist circumference, lipid profile, blood glucose or systolic blood pressure (Yamada et al. 2012). Karamese et al. (2015) reported a striking difference in Adv36 positivity in obese vs. non-obese Turkish adults (17.5\% vs. $4.0 \%)$, while an Italian population showed a positive association of Adv36 antibodies not only with obesity but also with essential hypertension (Trovato et al. 2009). A longitudinal follow-up of Adv36 seropositivity in young Finns revealed that individuals who became obese in adulthood exhibited Adv36 seropositivity significantly more frequently than those who maintained normal weight $-21.3 \%$ vs. $11.6 \%$ (Sabin et al. 2015). However, these authors were unable to find any significant difference in BMI between Adv36 positive and negative subjects across the life-course.

Several other studies in adults have failed to confirm the association of antibodies to Adv36 with obesity. Broderick et al. (2010) demonstrated an association of $\operatorname{Adv} 36$ seropositivity with age, race and sex in US military personnel, but not with obesity and lipid profile. Similarly, a study conducted with US Air Force male enlistees failed to show a relationship of Adv36 seropositivity to BMI (Voss et al. 2014). Adv36 infected individuals who were lean at baseline, however, exhibited a 3.9 times greater risk of being clinically diagnosed as overweight/obese over time in comparison with uninfected lean subjects. No significant difference in Adv36 seropositivity between obese and normal weight persons was found in Belgium or the Netherlands (Goossens et al. 2011). The prevalence of seropositivity in this study increased with age and was not related to gender. This finding of an increasing prevalence of Adv36 seropositivity with age was later confirmed by Trovato et al. (2014). Goossens et al. (2011) failed to find Adv36 DNA in visceral fat obtained from 31 severely obese patients who underwent bariatric surgery. However, a subsequent comment on this article raised several weak points of the methodology, such as the repeated thawing and freezing of analyzed samples as well as the use of an inappropriate rabbit antibody that is not suitable as a control for human serum (Atkinson 2011b). The failure to prove the presence of Adv36 in adipose tissue by PCR might also have been due to the small size of adipose tissue used $(10 \mathrm{mg})$ in comparison to previous studies, where the weight of analyzed samples was much higher (1000 mg) (Atkinson 2011b). For likely the same reason, a recent study also did not detect Adv36 DNA in samples of human adipose tissue obtained by lipoaspiration, despite the fact that Adv36 seropositivity was confirmed (Ergin et al. 2015).

Salehian et al. (2010) described a diabetic patient with multiple medical problems who developed obesity characterized by the enlargement of visceral adipose tissue together with the accumulation of subcutaneous body fat in the neck and chest areas. Only a minor amount of subcutaneous fat was located in the upper extremities and abdomen. This patient further exhibited extremely low levels of serum lipids. Quantitative PCR analysis revealed Adv DNA in a sample of subcutanous adipose tissue obtained by biopsy, leading the authors to suggest that the development of this atypical visceral obesity might be caused by Adv36 infection (Salehian et al. 2010).

Adenovirus 36 seropositivity and its relation to overweight/obesity in children and adolescents

Associations of Adv36 antibody positivity with obesity and/or overweight have much been stronger in children and adolescents than in adults. In American children, positivity for Adv36 antibodies has been demonstrated in $22 \%$ of obese children compared to $7 \%$ of non-obese children (Gabbert et al. 2010). Similarly, a significant difference in the prevalence of $\operatorname{Adv} 36$ antibodies was found in Korean school children - $29 \%$ in obese vs. $14 \%$ in non-obese ( $\mathrm{Na}$ et al. 2010). Another 
study also confirmed a high prevalence of positivity for Adv36 antibodies in obese Korean children (30\%) (Atkinson et al. 2010). In that study, significantly higher BMI z-scores and waist circumference were found in infected compared to uninfected subjects. In 2011, Atkinson et al. (2011a) summarized the results of four studies on the prevalence of Adv36 antibody positivity in children. This meta-analysis included 559 children, in whom a higher prevalence of Adv36 infection was demonstrated in obese children (28\%) compared to nonobese children (10\%). Additionally, in a cohort of 424 Swedish children, the prevalence of Adv36 positivity in overweight/obese children reached $29 \%$ versus $20 \%$ in lean individuals (Almgren et al. 2012). We examined 1,179 Czech adolescents and found positivity for Adv36 antibodies in $21.5 \%$ of normal weight, $40.0 \%$ of overweight and $28.0 \%$ of obese individuals (AldhoonHainerová et al. 2014). Adv36 positivity was particularly marked in overweight girls, of whom $55.0 \%$ were Adv36 antibody positive. More frequent Adv36 positivity in overweight than in obese individuals ( $40.0 \%$ vs. $30.0 \%$ ) was also observed in Korean adults ( $\mathrm{Na}$ et al. 2012). There have been several explanations for this phenomenon (Aldhoon-Hainerová et al. 2014). The higher prevalence of Adv36 infection among overweight adolescent girls in our study may be due to their attempts to control body weight in response to social pressure to be slim. Lifestyle changes in these girls may have prevented weight gain and further progression from overweight to obesity. On the other hand, it could be hypothesized that overweight subjects represent a recently infected cohort while some obese subjects are those who were infected long ago and subsequently had antibody titers that dropped below the detection limits of currently available assays. Recently, two studies from Turkey (Cakmakliogullari et al. 2014, Karamese et al. 2015) and a study from Mexico (Parra-Rojas et al. 2013) have confirmed the association of Adv36 seropositivity with obesity in childhood. Surprisingly, in the last study Adv36 seropositivity was also associated with low highdensity lipoprotein (HDL) cholesterol levels (Parra-Rojas et al. 2013) but not with a better lipid profile. Only the study of Berger et al. (2014) failed to demonstrate an association of Adv36 seropositivity with adiposity in children. The same study, however, showed an association of Adv36 with inflammatory markers such as tumor necrosis factor-alpha (TNF-alpha), interleukin-6 and vascular endothelial growth factor. The generally observed more robust correlation of Adv36 infection with obesity in children compared to adults has led to speculation about the causal role of Adv36 infection in the current worldwide increase in prevalence of childhood obesity (Atkinson et al. 2011a).

\section{The mechanism of action of adenovirus 36}

Adv36 accelerates the differentiation of preadipocytes into adipocytes (Vangipuram et al. 2004, Pasarica et al. 2008) and stimulates fat accumulation in adipocytes, independently of insulin, dexamethasone and methyl-isobutyl-xanthine, substances acting as preadipocyte differentiation inducers (Rathod et al. 2009). Adv36, but not Adv2, upregulates the expression of early, intermediate and late genes of the adipogenic cascade.

Pasarica et al. (2008) demonstrated that Adv36 enhances the expression of genes involved in adipogenesis (CCAAT/enhancer binding protein beta, peroxisome proliferator-activated receptor-gamma, and fatty acid-binding protein) in human adipose-derived stem/stromal cells in vitro. Human adipose-derived stem/stromal cells harboring Adv36 DNA in their adipose tissue due to natural infection had a significantly greater ability to differentiate compared to their Adv36 DNAnegative counterparts. It has further been shown that the accumulation of fat stores in response to Adv36 infection is mediated by the Adv36 gene, known as E4orf1 that activates lipogenic enzymes within adipocytes (Rogers et al. 2008a). Lipogenic enzymes stimulated by E4orf1 include lipoprotein lipase and fatty acid synthase. Infection with Adv36, but not with Adv2, leads to the increased production of interleukin- 6 and the reduced production of plasminogen activator inhibitor-1(PAI-1) (Bouwman et al. 2008). In that study, Adv36 infection induced a state of chronic inflammation that led to the infiltration of adipose tissue with macrophages. Signs of chronic low-grade inflammation through the specific protein referred to as monocyte chemoattractant protein-1 (MCP-1) were also observed (Bouwman et al. 2008). The MCP-1 concentrations in Adv36 antibody-positive humans have been found to be higher than in those who were antibody negative, and mice lacking MCP-1 were protected from Adv36-induced inflammation and obesity (Na and Nam 2012).

An essential role in the regulation of energy balance is played by leptin, a hormone secreted by fat cells that affects the hypothalamic anorexigenic and orexigenic pathways (Jéquier 2002). The rate of leptin production is related to the degree of adiposity and 
gender. Obese humans have markedly higher plasma leptin levels relevant to the size of adipose tissue. Hyperleptinemia in obese subjects reflects a resistance to the effects of endogenous leptin (Rogers et al. 2008b). Adv36 in the presence of insulin was found to reduce leptin release from rat adipocytes by about $40 \%$ and at the same time increase glucose uptake by $93 \%$ (Vangipuram et al. 2007). The adipose tissue of rats infected with Adv36 showed twofold to fivefold lower leptin mRNA expression compared to the adipose tissue of controls matched by weight and body composition (Vangipuram et al. 2007). In a study in rats it was demonstrated that infection with Adv36 is accompanied by a decrease in the concentration of norepinephrine in the paraventricular nucleus as well as in serum corticosterone (Pasarica et al. 2006). There have as yet been no studies on the relation of Adv36 infection with serum cortisol secretion in humans.

\section{Adenovirus 36, insulin sensitivity and hepatic steatosis}

Several studies have been published on the relationship of adenoviral infection with insulin sensitivity and nonalcoholic fatty liver disease (Almgren et al. 2014, Trovato et al. 2010, 2012a, Vangipuram et al. 2007, Pasarica et al. 2006, Krishnapuram et al. 2011, Dhurandhar et al. 2011, Dhurandhar et al. 2014, Krishnapuram et al. 2013, Trovato et al. 2014). In one, Adv36 infection led to an increased uptake of glucose by adipose cells (Vangipuram et al. 2007). Intraperitoneal inoculation of $\operatorname{Adv} 36$ in rats induced not only accumulation of body fat, but also improved insulin sensitivity evaluated by the homeostasis model assessment of insulin resistance (HOMA-IR) (Pasarica et al. 2006). These favorable metabolic changes were reflected in an increase in the expression of several enzymes including peroxisome proliferator-activated receptor gamma in the visceral adipose tissue of infected animals. A recent Swedish study carried out in 1,734 adults found that human $\operatorname{Adv} 36$ is uncommon in type 2 diabetes and is associated with increased insulin sensitivity, particularly in women (Almgren et al. 2014). Adv36 seropositivity was associated with a lower prevalence of non-alcoholic fatty liver disease (NAFLD) and bright liver score determined by ultrasound (Trovato et al. 2010). In a multiple linear regression model, Adv36 seropositivity together with HDL cholesterol and HOMA-IR were able to explain the degree of hepatic steatosis (Trovato et al. 2010). Adv36 seropositive patients with NAFLD demonstrated lower insulin resistance and fatty liver severity compared to individuals with NAFLD who were seronegative (Trovato et al. 2014). In contrast to Adv36, which appears to be a hepatoprotective factor in terms of fatty liver, Adv37 seropositivity was significantly associated with NAFLD. Trovato et al. (2012b) suggested Adv37 positivity as a causative factor of NAFLD.

Both experimental and clinical studies have confirmed the antidiabetogenic effect of infection with Adv36 (Krishnapuram et al. 2011). Adv36 improved glycemic control in mice fed either a standard or high-fat diet. Moreover, in mice fed with the high-fat diet, Adv36 infection prevented the development of hepatic steatosis. Adv36-infected mice exhibited not only a lower hepatic lipid content, but also a significant increase in glycogen content compared to uninfected controls. Adv36 infection favorably affects glucose homeostasis by increasing glucose uptake in adipose tissue and muscle. Adv36 infection simultaneously reduces its release from the liver. As shown in human muscle cells obtained from both non-diabetic normal weight subjects and patients with type 2 diabetes, Adv36 upregulates distal insulin signaling without recruiting proximal insulin signaling (Krishnapuram et al. 2011). In a cohort of 1,507 adults and children recruited from four clinical studies, Adv36 infection predicted better glycemic control and reduced hepatic fat content independently of age, sex, and adiposity (Krishnapuram et al. 2011). The mechanism by which Adv36 infection affects glucose uptake is independent of insulin and is mediated via Ras-activated phosphatidylinositol 3-kinase (PI 3-kinase). Adv36 increases gene expression and the abundance of glucose transporters such as GLUT1 and GLUT4 (Wang et al. 2008). The observed significant increase in concentrations of all free forms of adiponectin in adipose tissue in response to Adv36 infection in mice fed a high fat diet may contribute to a favorable metabolic profile in infected subjects (Krishnapuram et al. 2011).

The adipose tissue hormone adiponectin is known to improve insulin sensitivity and prevent the development of metabolic syndrome (Nedvídková et al. 2005). Metabolically favorable remodeling of human adipose tissue by Adv36 has been suggested. Adv36 in explants of human adipose tissue increase glucose uptake, the expression of several adipogenic genes, adiponectin, and fatty acid synthase, while the expression of proinflammatory MCP-1 is suppressed (Rogers et al. 2008b). A recent Chinese study carried out in overweight Uygur subjects revealed that preadipocytes infected with 
Adv36 have increased gene expressions of both adiponectin and visfatin (Jiao et al. 2014). The authors suggested that adiponectin and visfatin genes may be involved in the mechanism underlying the effects of Adv36 infection in obese individuals. Nevertheless, from a clinical point of view the inoculation of adipogenic adenovirus to "remodel" human adipose tissue in order to prevent or treat diabetes does not seem reasonable. It has therefore been investigated whether E4orf1 protein produced by the virus could be responsible for its antidiabetogenic properties while devoid of the virus's proinflammatory effects (Dhurandhar et al. 2011, 2012, Krishnapuram et al. 2013, Na et al. 2014). A series of experiments demonstrated that the E4orf1 protein is a factor that activates Ras and PI3K and thus leads to increased glucose uptake in Adv36 infected subjects. In vitro experiments showed that E4orf1 affects glucose homeostasis not only by increasing glucose uptake in preadipocytes, adipocytes and myoblasts, but also by reducing the output of glucose from liver cells (Dhurandhar et al. 2011). Both Adv36 and its E4orf1 gene enhance cellular glucose uptake ( $\mathrm{Na}$ et al. 2014). Adv36 but not E4orfl stimulates an inflammatory response as demonstrated by increased mRNA of MCP-1 and TNF-alpha.

\section{Adenovirus 36 and weight loss}

Only three studies so far have focused on the role of Adv36 infection in weight loss. All were carried out in children and demonstrated that fat stores are preserved in response to a short-term weight management program. Weight loss during a 4-week summer weightloss camp in 73 young subjects aged 10-17 years was studied by Vander Wal et al. (2013). At baseline, Adv36 seropositive and negative children did not differ in anthropometric and fitness measures, but Adv36 positive individuals showed lower levels of cholesterol and triglycerides. In response to a 4-week weight management program, Adv36 seropositive youth exhibited a smaller reduction in BMI percentile than those who were Adv36 seronegative (Vander Wal et al. 2013). Na et al. (2014) compared exercise-induced weight loss in Adv36 seropositive and seronegative subjects, using both humans (children aged 12-14 years who underwent a 2-month exercise program) and experimental animals (mice exposed to treadmill exercise for 12 weeks). Children with Adv36 seropositivity had higher initial BMI z-scores compared to their seronegative counterparts. In addition, seropositive children failed to lose weight in response to negative energy balance induced by exercise, in contrast to seronegative subjects. Similar results, i.e. resistance to weight loss, were demonstrated in exercising Adv36 infected mice. Exercise, even in the absence of weight loss, resulted in improved glycemic and lipid profile and increased mitochondrial activity in the liver. Despite regular physical activity Adv36 infected mice maintained chronic inflammation of adipose tissue ( $\mathrm{Na}$ et al. 2014).

In our recent study, the response to a 4-week in-patient weight management program was evaluated in 184 obese adolescent girls with respect to the antibody status of Adv36 (Zamrazilová et al. 2015). Significantly greater decreases in z-scores of waist circumference, waist-to-hip ratio and waist-to-height ratio were observed in Adv36 positive compared to Adv36 negative girls. On the other hand, the sum of four skinfolds decreased significantly more in Adv36 negative than in Adv36 positive subjects. We concluded that energy restriction in infected girls was associated with a greater reduction in abdominal obesity and the preservation of subcutaneous adipose stores than in those uninfected.

\section{Infection as a complication of obesity}

\section{Alterations of immune function in obesity}

Obesity has been associated with altered immune function since the nineties (Nieman et al. 1996, 1999, Tanaka et al. 1993). Nieman et al. reported suppressed mitogen-induced lymphocyte proliferation in obese women (Nieman et al. 1996, 1999). This marker of deteriorated $\mathrm{T}$ - and B-cell function may contribute to a greater susceptibility of obese subjects to infection. Impaired T-lymphocytes may be associated with the increased secretion of proinflammatory adipokines, such as TNF-alpha (Tanaka et al. 1993, 2001). A decreased function of both macrophage and dendritic cells was also demonstrated in obese human subjects (Nieman et al. 1999). Moreover, metabolically-risky obesity has been shown to be associated with the impaired function of natural killer cells (Lynch et al. 2008).

\section{Obesity and respiratory infections}

Severe obesity is associated with impaired bronchopulmonary function. In addition, obese individuals are more susceptible to respiratory infections (Jubber 2004). Overweight preadolescent children have twice as high a risk for acute respiratory infections than children with low BMI (Jedrychowski et al. 1998). Phung 
et al. (2013) performed a meta-analysis of the relationship between BMI and pneumonia, which found a J-shaped relationship between BMI and the risk of community-acquired pneumonia but a U-shaped relationship between BMI and the risk of influenzarelated pneumonia. Obesity was identified as a novel risk factor for the H1N1 influenza infection that reached pandemic proportions in 2009 (Louie et al. 2011). Half of adult Californians hospitalized with H1N1 infection in 2009 were obese. It has recently been demonstrated that obesity was associated with severe outcomes following the $2009 \mathrm{H} 1 / \mathrm{N} 1$ influenza pandemic (Almond et al. 2013). The risk of death due to H1N1 infection significantly increases in obese patients with BMI $\geq 30$ $\mathrm{kg} / \mathrm{m}^{2}$ (risk ratio: 3.1 ) and even more in those with BMI $\geq 40 \mathrm{~kg} / \mathrm{m}^{2}$ (risk ratio: 7.6) (Louie et al. 2011). Obesity also increased the risk of disease severity (risk ratio: 3.28) in children during the 2009-2010 influenza virus pandemic (Garcia et al. 2015). Besides the impairment of dendritic and memory T-cells (Nieman et al. 1999, Karlsson et al. 2010), further factors contribute to a greater susceptibility of obese individuals to influenza virus infection, e.g. reduced interferons (alpha, beta and gamma) mRNA expression, and increased viral titers and virus infiltration of the target tissues ( $\mathrm{Hu}$ et al. 2013). Polymorphisms of the fat mass and obesity associated (FTO) gene have been associated with obesity (Hinney et al. 2007). Feng et al. (2014) recently reported that the FTO variant rs9939609 is associated with a risk of pulmonary tuberculosis in Chinese population.

\section{Neisseria meningitidis and Helicobacter pylori in obesity}

Obese children have a three times greater risk of being carriers of Neisseria meningitidis than non-obese subject, and this risk increases with the severity of BMI (Uberos et al. 2010). A higher prevalence of Helicobacter pylori infection was observed in Turkish obese subjects compared to normal weight controls, with the authors suggesting that obesity could be considered a risk factor for Helicobacter pylori infection (Arslan et al. 2009). On the contrary, a recent review article summarized the data concerning an association of Helicobacter pylori infection with obesity and found conflicting results (Carabotti et al. 2014).

\section{Obesity and nosocomial infections}

Obesity is a serious risk factor for nosocomial infections, particularly infections located at surgical sites (Anaya and Dellinger 2006). An increased incidence of nosocomial infections has been repeatedly described in surgical patients (Choban et al. 1995, Canturk et al. 2003). Obesity defined by percent body fat is associated with a 5-fold increase in surgical site infections (Weisbren et al. 2010). Obesity was also shown to be an independent risk factor for intensive care unit-acquired catheter and blood stream infections (Dossett et al. 2009).

\section{Obesity and response to vaccinations}

Several studies have found that obese individuals have decreased antibody formation in response to vaccinations. A poor response to hepatitis $B$ vaccination in obese subjects has been reported in studies conducted in both adults and adolescents (Weber et al. 1985, 1986). Reduced tetanus antibody titers were described in overweight children (Eliakim et al. 2006). In another study, obesity probably contributed to an impaired immune response to influenza vaccination at 12 months following vaccination, although a higher BMI was associated with higher antibodies titers one month after vaccination (Sheridan et al. 2012). At 12 months after influenza vaccination, a higher BMI was associated with a greater decline in IgG antibodies.

\section{Future challenges and expectations}

Many challenges remain to be addressed in future research on the association between infection and obesity. Scientists should search for other infections in addition to Adv36 that could be considered pathogenic agents in human obesity. New specific and simple tests for the diagnosis of infected subjects should be developed, which could be widely used in clinical practice. More information about the dynamics of Adv36 seropositivity is expected as well as data about the distribution of Adv36 in human tissues besides adipose stores. It would be helpful to know how long the infection persists in tissues and exerts its adipogenic, proinflamamtory, hypolipidemic and insulin-sensitizing effects. The relationship between Adv36 seropositivity and the presence of Adv DNA in tissues should also be clarified. The prevalence of Adv36 infection needs to be studied in larger cohorts in different populations, and the role of ethnicity, genetic and immune susceptibility, age and gender in variations in prevalence should be evaluated. Such comprehensive studies could provide sophisticated data on the role of Adv36 infection in the development of metabolically-healthy obesity, a disease with a highly variable prevalence in the obese from $18 \%$ 
to $44 \%$ (Primeau et al. 2011).

Our knowledge on Adv36 will open new horizons in the prophylaxis and treatment of obesity and its metabolic complications. This has been elegantly demonstrated by recent experimental studies in mice using ultraviolet-irradiated virus as a vaccine candidate and comparing the response to inoculation of live Adv36 between vaccinated and unvaccinated mice ( $\mathrm{Na}$ and $\mathrm{Nam}$ 2014). Vaccinated mice had lower body weight, decreased levels of pro-inflammatory cytokines and a decreased number of macrophages in adipose tissue compared to unvaccinated mice. Nevertheless, before the potential introduction of prophylactic vaccination against virus-induced obesity to clinical practice, multiple studies in both experimental animals and humans will be required. Adv36 E4orf1 protein, with its insulin sensitizing properties devoid of pro-inflammatory effects, offers another therapeutic potential. For the future, it seems reasonable to test this agent in the treatment of type 2 diabetes, nonalcoholic fatty liver disease and lipodystrophy. At the same time, it will be necessary to test the efficacy, tolerability and adverse effects, particularly with respect to its oncogenic potential (Kumar et al. 2014).

Further research will also be required to extend our knowledge on the role of obesity in infectious diseases (Karlsson and Beck 2010). Reasons for the poor response of obese individuals to vaccination need to be elucidated, and appropriate interventions to prevent this should be initiated. Various factors, including different weight management strategies that are able to improve impaired immune function in obesity, should be identified and employed in clinical practice in order to prevent the unfavorable outcomes of infectious diseases, particularly in severely obese patients.

\section{Conflict of Interest}

There is no conflict of interest.

\section{Acknowledgements}

This study was supported by the project (Ministry of Health, Czech Republic) for conceptual development of Research organization 00023761 (Institute of Endocrinology, Prague, Czech Republic) and NT/13792-4 Internal Grant Agency of the Ministry of Health of the Czech Republic.

\begin{abstract}
Abbreviations
Adv, adenovirus; BDV, Borna disease virus; BMI, body mass index; CDV, Canine distemper virus; DNA, deoxyribonucleic acid; GLP-1, glucagon like peptide-1; GLUT, glucose transporter; HDL, high density lipoprotein; HOMA-IR, homeostasis model assessment of insulin resistance; LDL, low density lipoprotein; MCP-1, monocyte chemoattractant protein-1; PAI-1, plasminogen activator inhibitor; NAFLD, non-alcoholic fatty liver disease; PCR, polymerase chain reaction; PI3K, phosphatidylinositol 3-kinase; RAV-7, Rous-associated virus-7; TNF-alpha, tumor necrosis factor-alpha.
\end{abstract}

\section{References}

ALDHOON-HAINEROVÁ I, ZAMRAZILOVÁ H, ATKINSON RL, DUŠÁTKOVÁ L, SEDLÁČKOVÁ B, HLAVATÝ P, LEE ZP, KUNEŠOVÁ M, HAINER V: Clinical and laboratory characteristics of 1179 Czech adolescents evaluated for antibodies to human adenovirus 36. Int J Obes (Lond) 38: 285-291, 2014.

ALMGREN M, ATKINSON R, HE J, HILDING A, HAGMAN E, WOLK A, THORELL A, MARCUS C, NASLUND E, OSTENSON C-G, SCHALLING M, LAVEBRATT C: Adenovirus-36 is associated with obesity in children and adults in Sweden as determined by rapid ELISA. PLoS One 7: e41652, 2012.

ALMGREN M, ATKINSON RL, HULDING A, HE J, BRISMAR R, SCHALLING M, OSTENSON CG, LAVEBRATT C: Human adenovirus-36 is uncommon in type 2 diabetes and is associated with increased insulin sensitivity in adults in Sweden. Ann Med 46: 539-546, 2014.

ALMOND MH, EDWARDS MR, BARCLAY WS, JOHNSTON SL: Obesity and susceptibility to severe outcome following respiratory viral infection. Thorax 68: 684-686, 2013.

ANAYA DA, DELLINGER EP: The obese surgical patient: a susceptible host for infection. Surg Infect (Larchmt) 7: 473-480, 2006.

ARSLAN E, ATILGAN H, YAVASOGLU I: The prevalence of Helicobacter pylori in obese subjects. Eur J Intern Med 20: 695-697, 2009.

ATKINSON RL: Viruses as an etiology of obesity. Mayo Clin Proc 82: 1192-1198, 2007.

ATKINSON RL: Human adenovirus-36 and childhood obesity. Int J Pediatr Obes 6 (Suppl 1): 2-6, 2011 a. 
ATKINSON RL: Prevalence of infection with adenovirus-36 in Belgium and Holland and association with obesity. Obesity (Silver Spring) 19: 2, $2011 \mathrm{~b}$.

ATKINSON RL, DHURANDHAR NV, ALLISON DB, BOWEN RL, ISRAEL BA, ALBU JB, AUGUSTUS AS: Human adenovirus-36 is associated with increased body weight and paradoxical reduction of serum lipids. Int J Obes (Lond) 29: 281-286, 2005.

ATKINSON RL, LEE I, SHIN HJ, HE J: Human adenovirus-36 antibody status is associated with obesity in children. Int J Pediatr Obes 5: 157-160, 2010.

BERGER PK, POLLOCK NK, LAING EM, WARDEN SJ, HILL GALLANT KM, HAUSMAN DB, TRIPP RA, MCCABE LD, MCCABE GP, WEAVER CM, PEACOCK M, LEWIS RD: Association of adenovirus 36 infection with adiposity and inflammatory markers in children. J Clin Endocrinol Metab 99: 3240-3246, 2014.

BERNARD A1, COHEN R, KHUTH ST, VEDRINE B, VERLAETEN O, AKAOKA H, GIRAUDON P, BELIN MF: Alteration of the leptin network in late morbid obesity induced in mice by brain infection with canine distemper virus. $J$ Virol 73: 7317-7327, 1999.

BIL-LULA I, DE FRACESCHI N, PAWLIK K, WOZNIAK M: Improved real-time PCR assay for detection and quantification of all 54 known types of human adenoviruses in clinical samples. Med Sci Monit 18: BR221BR228, 2012.

BOUWMAN JJ, VISSEREN FL, BOUTER KP, DIEPERSLOOT RJ: Infection-induced inflammatory response of adipocytes in vitro. Int $J$ Obes (Lond) 32: 892-901, 2008.

BRODERICK MP, HANSEN CJ, IRVINE M, METZGAR D, CAMBELL K, BAKER C, RUSSELL KL: Adenovirus 36 seropositivity is strongly associated with race and gender, but not obesity, among US military personal. Int J Obes (Lond) 34: 302-308, 2010.

CAKMAKLIOGULLARI EK, SANLIDAG T, ERSOY B, AKCALI S, VAR A, CICEK C: Are human adenovirus-5 and 36 associated with obesity in children? J Investig Med 62: 821-824, 2014.

CANTURK Z, CANTURK NZ, CETINARSLAN B, UTKAN NZ, TARKUN I: Nosocomial infections and obesity in surgical patients. Obes Res 11: 769-775, 2003.

CARABOTTI M, D'ERCOLE C, IOSSA A, CORAZZIARI E, SIULECCHIA G, SEVERI C: Helicobacter pylori infection in obesity and its clinical outcome after bariatric surgery. World J Gastroenterol 20: 647-653, 2014.

CARP RI, KIM YS, CALLAHAN SM: Pancreatic lesions and hypoglycemia-hyperinsulinemia in scrapie-injected hamsters. J Infect Dis 161: 462-466, 1990.

CARTER JK, OW CL, SMITH RE: Rous-associated virus type 7 induces a syndrome in chickens characterized by stunting and obesity. Infect Immun 39: 410-422, 1983.

CHOBAN PS, HECKLER R, BURGE JC, FLANCBAUM L: Increased incidence of nosocomial infections in obese surgical patients. Am Surg 61: 1001-1005, 1995.

DART AM, MARTIN JL, KAY S: Association between past infection with Chlamydia pneumoniae and body mass index, low-density lipoprotein particle size and fasting insulin. Int J Obes Relat Metab Disord 26: 464-468, 2002.

De JONG JC, WIGAND R, WADELL G, KELLER D, MUZERIE CJ, WERMENBOL AG, SCHAAP GJ: Adenovirus 37: identification and characterization of a medically important new adenovirus type of subgroup D. $J$ Med Virol 7: 105-118, 1981.

DHURANDHAR EJ, DUBUISSON O, MASHTALIR N, KRISHNAPURAM R, HEDGE V, DHURANDHAR NV: E4orf1: novel ligand that improves glucose disposal in cell culture. PLoS One 6: e23394, 2011.

DHURANDHAR EJ, KRISHNAPURAM R, HEDGE V, DUBUISSON O, TAO R, DONG XC, YE J, DHURANDHAR NV: E4orf1 improves lipid and glucose metabolism in hepatocytes: a template to improve steatosis \& hyperglycemia. PLoS One 7: e47813, 2012.

DHURANDHAR NV: Infectobesity: obesity of infection origin. J Nutr 131: 2794S-2797S, 2001.

DHURANDHAR NV, KULKARNI PR, AJINKYA SM, SHERIKAR AA: Avian adenovirus leading to pathogenic obesity in chickens. J Bombay Vet College 2: 131-132, 1990.

DHURANDHAR NV, KULKARNI PR, AJINKYA SM, SHERIKAR AA: Effect of adenovirus infection on adiposity in chicken. Vet Microbiol 31: 101-107, 1992.

DHURANDHAR NV, KULKARNI PR, AJINKYA SM, SHERIKAR AA, ATKINSON RL: Association of adenovirus infection with human obesity. Obes Res 5: 464-469, 1997. 
DHURNDHAR NV, ISRAEL BA, KOLESAR JM, MAYHEW GF, COOK ME, ATKINSON RL: Increased adiposity in animals due to a human virus. Int J Obes Relat Metabol Disord 24: 989-996, 2000.

DHURANDHAR NV, ISRAEL BA, KOLESAR JM, MAYHEW G, COOK ME, ATKINSON RL: Transmissibility of adenovirus-induced adiposity in a chicken model. Int J Obes Relat Metab Disord 25: 990-996, 2001.

DHURANDHAR NV, WHIGHAM LD, ABBOTT DH, SCHULZ-DARKEN NJ, ISRAEL BA, BRADLEY SM, KEMNITZ JW, ALLISON DB, ATKINSON RL: Human adenovirus Ad-36 promotes weight gain in male rhesus and marmoset monkeys. J Nutr 132: 3155-3160, 2002.

DHURANDHAR NV, DHURANDHAR EJ, INGRAM DK, VAUGHAN K, MATTISON JA: Natural infection of human adenovirus 36 in rhesus monkeys is associated with a reduction in fasting glucose. $J$ Diabetes $\mathbf{6}$ : 614-616, 2014.

DOSSETT LA, DAGEFORDE LA, SWENSON BR, METZGER R, BONATTI H, SAWYER RG, MAY AK: Obesity and site-specific nosocomial infection risk in the intensive care unit. Surg Infect (Larchmt) 10: 137-142, 2009.

DUBUISSON O, DAY RS, DHURANDHAR NV: Accurate identification of neutralizing antibodies to adenovirus AD-36, - a putative contributor of obesity in humus. J Diabetes Complications 29: 83-87, 2015.

DUŠÁTKOVÁ L, ZAMRAZILOVÁ H, ALDHOON-HAINEROVÁ I, ATKINSON RL, SEDLÁČKOVÁ B, LEE ZP, VČELÁK J, BENDLOVÁ B, KUNEŠOVÁ M, HAINER V: Association of adenovirus 36 infection with obesity-related gene variants in adolescents. Physiol Res 64 (Suppl 2): S197-S202, 2015.

EKESBO R, NILSSON PM, LINDHOLM LH, PERSSON K, WADSTROM T: Combined seropositivity for H. pylori and C. pneumoniae is associated with age, obesity and social factors. J Cardiovasc Risk 7: 191-195, 2000.

ELIAKIM A, SCHWINDT C, ZALDIVAR F, CASALI P, COOPER DM: Reduced tetanus antibody titers in overweight children. Autoimmunity 39: 137-141, 2006.

ERGIN S, ALTAN E, PILANCI O, SIREKBASAN S, CORTUK O, ERSIN I, ELBEY H, DINC HO, HABIP Z, TURAN N, ARINCI A, RICHT JA, GOODENS VJ, KARAKULLUKCU A, KOCAK BT, SARIBAS S, KOKSAL S, YILMAZ H, KOCAZEYBEK B: The role of adenovirus 36 as a risk factor in obesity: the first clinical study made in the fatty tissues of adults in Turkey. Microb Pathog 80: 57-62, 2015.

FENG Y, WANG F, PAN H, QIU S, LU J, WU L, WANG J, LU C: Obesity associated gene FTO rs9939609 polymorphism in relation to the risk of tuberculosis. BMC Infectious Diseases 14: 592, 2014.

FIELD BC, CHAUDRI OB, BLOOM SR: Bowels control brain: gut hormones and obesity. Nat Rev Endocrinol 6: 444-453, 2010.

GABBERT C, DONOHUE M, ARNOLD J, SCHWIMMER JB: Adenovirus 36 and obesity in children and adolescents. Pediatrics 126: 721-726, 2010.

GARCIA MN, PHILPOTT DC, MURRAY KO, ONTIVEROS A, REVELL PA, CHANDRAMOHAN L, MUNOZ FM: Clinical predictors of disease severity during the 2009-2010 A(H1N1) influenza virus pandemic in a paediatric population. Epidemiol Infect 143: 2939-2949, 2015.

GOOSSENS VJ, DE JAGER SA, GRAULS GE, GIELEN M, VLIETINCK RF, DEROM CA, LOOS RJ, RENSEN SS, BUURMAN WA, GREVE JW, VAN BAAK MA, WOLFFS PF, BRUGGEMAN CA, HOEBE CJ: Lack of evidence for the role of human adenovirus-36 in obesity in a European cohort. Obesity (Silver Spring) 19: 220-221, 2011.

GOSZTONYI G, LEDWIG H: Borna disease - neuropathology and pathogenesis. Curr Top Microbiol Immunol 190: 39-73, 1995.

GRIFFOND B, VERLAETEN O, BELIN MF, RISOLD PY, BERNARD A: Specific alteration of the expression of selected hypothalamic neuropeptides during acute and late mouse brain infection using a morbilli virus: relevance to the late-onset obesity? Brain Res 1022: 173-181, 2004.

HINNEY A, NGUYEN TT, SCHERAG A, FRIEDEL S, BRONNER G, MULLER TD, GRALLERT H, ILLIG T, WICHMANN HE, RIEF W, SCHAFER H, HEBEBRAND J: Genome wide association (GWA) study for early onset extreme obesity supports the role of fat mass and obesity associated gene (FTO) variants. PLoS One 2: e1361, 2007.

HU SJ, KIM DH, CHUN SC, LEE SK: Effect of adenovirus and influenza virus infection on obesity. Life Sci 93: 531-535, 2013.

JAWOROWSKA A, BAZYLAK G: Chlamydophila pneumoniae antibodies may be independently associated with increased BMI and percentage of body fat among women. Int J Obes (Lond) 35: 1225-1232, 2011. 
JEDRYCHOWSKI W, MAUGERI U, FLAK E, MROZ E, BIANCHI I: Predisposition to acute respiratory infections among overweight preadolescent children: an epidemiologic study in Poland. Public Health 112: 189-195, 1998.

JÉQUIER E: Leptin signaling, adiposity, and energy balance. Ann NY Acad Sci 967: 379-388, 2002.

JIAO Y, MAO X, CHANG X, ABUDUREYIMU K, ZHANG C, LU J, WANG Y, NUERMAIMAITI N, AISA Y, GONG X, GUAN Y: Adenovirus36 infection expresses cellular APMI and visfatin genes in overweight Uygur individuals. Diagn Pathol 9: 83, 2014.

JUBBER A: Respiratory complications of obesity. Int J Clin Pract 58: 573-580, 2004.

KARAMESE M, ALTOPARLAK U, TURGUT A, AYDOGDU S, KARAMESE SA: The relationship between adenovirus-36 seropositivity, obesity and metabolic profile in Turkish children and adults. Epidemiol Infect in press 2015.

KARLSSON EA, BECK MA: The burden of obesity on infectious disease. Exp Biol Med (Maywood) 235: 1412-1424, 2010.

KARLSSON EA, SHERIDAN PA, BECK MA: Diet-induced obesity impairs the T cell memory response to influenza virus. J Immunol 184: 3127-3133, 2010.

KIM YS, CARP RI, CALLAHAN SM, WISNIEWSKI HM: Scrapie-induced obesity in mice. J Infect Dis 156: 402-405, 1987.

KIM YS, CARP RI, CALLAHAN SM, WISNIEWSKI HM: Adrenal involvement in scrapie-induced obesity. Proc Soc Exp Biol Med 189: 21-27, 1988.

KRISHNAPURAM R, DHURANDHAR EJ, DUBUISSON O, KIRK-BALLARD H, BAJPEYI S, BUTTE N, SOTHERN MS, LARSEN-MEYER E, CHALEW S, BENNETT B, GUPTA AK, GREENWAY FL, JOHNSON W, BRASHEAR M, REINHART G, RANKINEN T, BOUCHARD C, CEFALU WT, YE J, JAVIER R, ZUBERI A, DHURANDHAR NV: Template to improve glycemic control without reducing adiposity or dietary fat. Am J Physiol Endocrinol Metab 300: E779-E789, 2011.

KRISHNAPURAM R, DHURANDHAR EJ, DUBUISSON O, HEDGE V, DHURANDHAR NV: Doxycyclineregulated 3T3-L1 preadipocyte cell line with inducible, stable expression of adenoviral E4orfl gene: a cell model to study insulin-independent glucose disposal. PLoS One 8: e60651, 2013.

KUMAR M, KONG K, JAVIER RT: Hijacking Dlg1 for oncogenic phosphatidylinositol 3-kinase activation in human epithelial cells is conserved mechanism of human adenovirus E4-ORF1 proteins. J Virol 88: 14268-14277, 2014.

LAJUNEN T, BLOIGU A, PALDANIUS M, POUTA A, LAITINEN J, RUOKONEN A, HARTIKAINEN AL, SAVOLAINEN M, HERZIG KH, LEINONEN M, SAIKKU P, JARVELIN MR: The association of body mass index, waist and hip circumference, and waist-hip ratio with Chlamydia pneumoniae IgG antibodies and high-sensitive C-reactive protein at 31 years of age in Northern Finland Birth Cohort 1966. Int J Obes (Lond) 35: 1470-1478, 2011.

LOUIE JK, ACOSTA M, SAMUEL MC, SCHECHTER R, VUGIA DJ, HARRIMAN K, MATYAS BT; THE CALIFORNIA PANDEMIC (H1N1) WORKING GROUP: A novel risk factor for a novel virus: obesity and 2009 pandemic influenza A (H1N1). Clin Infect Dis 52: 301-312, 2011.

LYONS MJ, FAUST IM, HEMMES RB, BUSKIRK DR, HIRSCH J, ZABRISKIE JB: A virally induced obesity in mice. Science 216: 82-85, 1982.

LYNCH LA, O'CONNELL JM, KWASNIK AK, CAWOOD TJ, O'FARRELLY C, O'SHEA DB: Are natural killer cells protecting the metabolically healthy obese patient? Obesity 17: 601-605, 2008.

MCALLISTER EJ, DHURANDHAR NV, KEITH SW, ARONNE LJ, BARGER J, BASKIN M, BENCA RM, BIGGIO J, BOGGIANO MM, EISENMANN JC, ELOBEID M, FONTAINE KR, GLUCKMAN P, HANLON EC, KATZMARZYK P, PIETROBELLI A, REDDEN DT, RUDEN DM, WANG C, WATERLAND RA, WRIGHT SM, ALLISON DB: Ten putative contributors to the obesity epidemic. Crit Rev Food Sci Nutr 49: 868-913, 2009.

MOKDAD AH, FORD ES, BOWMAN BA, DIETZ WH, VINICOR F, BALES VS, MARKS JS: Prevalence of obesity, diabetes, and obesity-related health risk factors, 2001. JAMA 289: 76-79, 2003.

NA HN, NAM JH: Adenovirus 36 as an obesity agent maintains the obesity state by increasing MCP-1 and inducing inflammation. J Infect Dis 205: 914-922, 2012. 
NA HN, NAM JH: Proof-of-concept for a virus-induced obesity vaccine; vaccination against the obesity agent adenovirus 36. Int J Obes (Lond) 38: 1470-1474, 2014.

NA HN, HONG YM, KIM J, KIM HK, JO I, NAM JH: Association between human adenovirus-36 and lipid disorders in Korean schoolchildren. Int J Obes (Lond) 34: 89-93, 2010.

NA HN, KIM J, LEE HS, SHIM KV, KIMM H, JEE SH, JO I, NAM JH: Association of human adenoviorus-36 in overweight Korean adults. Int J Obes (Lond) 36: 281-285, 2012.

NA HN, HONG YM, YE MB, PARK S, KIM IB, NAM JH: Adenovirus 36 attenuates weight loss from exercise but improves glycemic control by increasing mitochondrial activity in the liver. PLoS One 9: e114534, 2014.

NA HN, DUBUISSON O, HEDGE V, NAM JH, DHURANDHAR NV: Human adenovirus AD36 and its E4orf1 gene enhance cellular glucose uptake even in the presence of inflammatory cytokines. Biochimie in press 2014.

NEDVÍDKOVÁ J, SMITKA K, KOPSKÝ V, HAINER V: Adiponectin, an adipocyte derived protein. Physiol Res 54: 133-140, 2005.

NIEMAN DC, NEHLSEN-CANNARELLA SL, HANSON DA, BUTTERWORTH DE, FAGOAGA OR, WARREN BJ, RAINWATER MK: Immune response to obesity and moderate weight loss. Int J Obes Relat Metabol Disord 20: 353-360, 1996.

NIEMAN DC, HANSON DA, NEHLSEN-CANNARELLA SL, EKKENS M, UTTER AC, BUTTERWORTH DE, FAGOAGA OR: Infuence of obesity on immune function. J Am Diet Assoc 99: 294-299, 1999.

PARRA-ROJAS I, DEL MORAL-HERNÁNDEZ O, SALGADO-BERNABÉ AB, GUZMÁN-GUZMÁN IP, SALGADO-GOYTIA L, MUNOZ-VALLE JF: Adenovirus-36 seropositivity and its relation with obesity and metabolic profile in children. Int J Endocrinol 2013: 463194, 2013.

PASARICA M, SHIN AC, YU M, OU YANG HM, RATHOD M, JEN KL, MOHAN KUMAR S, MOHAN KUMAR PS, MARKWARD N, DHURANDHAR NV: Human adenovirus 36 induces adiposity, increases insulin sensitivity and alters hypothalamic monoamines in rats. Obesity (Silver Spring) 14: 1905-1913, 2006.

PASARICA M, MASHTALIR N, MCALLISTER EJ, KILROY GE, KOSKA J, PERMANA P, DE COURTEN B, YU M, RAVUSSIN E, GIMBLE JM, DHURANDHAR NV: Adipogenic human adenovirus Ad-36 induces commitment, differentiation, and lipid accumulation in human adipose-derived stem cells. Stem Cells 26: 969-978, 2008.

PHUNG DT, WANG Z, RUTHERFORD S, HUANG C, CHU C: Body mass index and risk of pneumonia: a systematic review and metaanalysis. Obes Rev 14: 839-857, 2013.

PRIMEAU V, CODERRE L, KARELIS AD, BROCHU M, LAVOIE ME, MESSIER V, SLADEK R, RABASALHORET R: Characterizing the profile of obese patients who are metabolically healthy. Int J Obes (Lond) 35 : 971-981, 2011.

RATHOD MA, ROGERS PM, VANGIPURAM SD, MCALLISTER EJ, DHURANDHAR NV: Adipogenic cascade can be induced without adipogenic media by a human adenovirus. Obesity (Silver Spring) 17: 657-664, 2009.

ROGERS PM, FUSINSKI KA, RATHOD MA, LOILER SA, PASARICA M, SHAW MK, KILROY G, SUTTON GM, MCALLISTER EJ, MASHTALIR N, GIMBLE JM, HOLLAND TC, DHURANDHAR NV: Human adenovirus Ad-36 induces adipogenesis via its E4 orf-1 gene. Int J Obes (Lond) 32: 397-406, $2008 \mathrm{a}$.

ROGERS PM, MASHTALIR N, RATHOD MA, DUBUISSON O, WANG Z, DASURI K, BABIN S, GUPTA A, MARKWARD N, CEFALU WT, DHURANDHAR NV: Metabolically favorable remodelling of human adipose tissue by human adenovirus type 36. Diabetes 57: 2321-2331, 2008b.

SABIN MA, BURGNER D, ATKINSON RL, PEI-LUN LEE Z, MAGNUSSEN CG, CHEUNG M, KAHONEN M, LEHTIMAKI T, JOKINEN E, LAITINEN T, HUTRI-KAHONEN N, VIIKARI JS, JUONALA M, RAITAKARI OT: Longitudinal investigation of adenovirus 36 seropositivity and human obesity: The cardiovascular risk in young Finns study. Int J Obes (Lond) in press 2015.

SALEHIAN B, FORMAN SJ, KANDEEL F, BRUNER DE, HE J, ATKINSON RL: Adenovirus 36 DNA in adipose tissue of patient with unusual visceral obesity. Emerg Infect Dis 16: 850-852, 2010.

SHANG Q, WANG H, SONG Y, WEI L, LAVEBRATT C, ZHANG F, GU H: Serological data analyses show that adenovirus 36 infection is associated with obesity: a meta-analysis involving 5739 subjects. Obesity (Silver Spring) 22: 895-900, 2014. 
SHERIDAN PA, PAICH HA, HANDY J, KARLSSON EA, HUDGENS MG, SAMMON AB, HOLLAND LA, WEIR S, NOAH TL, BECK MA: Obesity is associated with impaired immune response to influenza vaccination in humans. Int J Obes 36: 1072-1077, 2012.

SO PW, HERLIHY AH, BELL JD: Adiposity induced by adenovirus 5 inoculation. Int J Obes (Lond) 29: 603-606, 2005.

STROM A, YUTZY B, KRUIP C, OOMS M, SCHLOOT NC, RODEN M, SCOTT FW, LOEWER J, HOLZNAGEL E: Foodborne transmission of bovine spongiform encephalopathy to non-human primates results in preclinical rapid-onset obesity. PLoS One 9: e104343, 2014.

TANAKA S, INOUE S, ISODA F, WASEDA M, ISHIHARA M, YAMAKAWA T, SUGIYAMA A, TAKAMURA Y, OKUDA K: Impaired immunity in obesity: suppressed but reversible lymphocytes responsiveness. Int $J$ Obes Relat Metab Disord 17: 631-636, 1993.

TANAKA S, ISODA F, ISHIHARA Y, KIMURA M, YAMAKAWA T: T lymphopaenia in relation to body mass index and TNF-alpha in human obesity: adequate weight reduction can be corrective. Clin Endocrinol (Oxf) 54: 347-354, 2001.

THJODLEIFFSON B, OLAFSSON I, GISLASON D, GISLASON T, JOGI R, JANSON C: Infections and obesity: a multinational epidemiological study. Scand J Infect Dis 40: 381-386, 2008.

TROVATO FM, CATALANO D, GAROZZO A, MARTINES GF, PIRRI C, TROVATO GM: ADV36 adipogenic adenovirus in human liver disease. World J Gastroenterol 20: 14706-14716, 2014.

TROVATO GM, MARTINES GF, GAROZZO A, TONZUSO A, TIMPANARO R, PIRRI C, TROVATO FM, CATALANO D: Ad36 adipogenic adenovirus in human non-alcoholic fatty liver disease. Liver Int 30: 184-190, 2010.

TROVATO GM, CASTRO A, TONZUSO A, GAROZZO A, MARTINES GF, PIRRI C, TROVATO F, CATALANO D: Human obesity relationship with AD36 adenovirus and insulin resistance. Int J Obes (Lond) 33: 1402-1409, 2009.

TROVATO GM, MARTINES GF, TROVATO FM, PIRRI C, PACE P, GAROZZO A, CASTRO A, CATALANO D: Adenovirus-36 seropositivity enhances effects of nutritional intervention on obesity, bright liver, and insulin resistance. Dig Dis Sci 57: 535-544, 2012a.

TROVATO GM, MARTINES GF, PIRRI C, TROVATO FM, CASTRO A, GAROZZO A, CATALANO D: Obesityindependent association of human adenovirus Ad37 seropositivity with nonalcoholic fatty liver disease. $J$ Clin Gastroenterol 46: e46-e54, 2012b.

UBEROS J, MOLINA-CARBALLO A, FERNÁNDEZ-PUENTES V, RODRÍGUEZ-BELMONTE R, MUNOZHOYOS A: Overweight and obesity as risk factors for the asymptomatic carrier state of Neisseria meningitidis among a paediatric population. Eur J Clin Microbiol Infect Dis 29: 333-334, 2010.

VANDER WAL JS, HUELSING J, DUBUISSON O, DHURANDHAR NV: An observational study of the association between adenovirus 36 antibody status and weight loss among youth. Obes Facts 6: 269-278, 2013.

VANGIPURAM SD, SHEELE J, ATKINSON RL, HOLLAND TC, DHURANDHAR NV: A human adenovirus enhances preadipocyte differentiation. Obes Res 12: 770-777, 2004.

VANGIPURAM SD, YU M, TIAN J, STANHOPE KL, PASARICA M, HAVEL PJ, HEYDARI AR, DHURANDHAR NV: Adipogenic human adenovirus-36 reduces leptin expression and secretion and increases glucose uptake by fat cells. Int J Obes (Lond) 31: 87-96, 2007.

VOSS JD, BURNETT DG, OLSEN CH, HAVERKOS HW, ATKINSON RL: Adenovirus 36 antibodies associated with clinical diagnosis of overweight/obesity but not BMI gain: a military cohort study. $J$ Clin Endocrinol Metab 99: E1708-E1712, 2014.

WANG ZQ, CEFALU WT, ZHANG XH, YU Y, QIN J, SON L, ROGERS PM, MASHTALIR N, BORDELON JR, YE J, DHURANDHAR NV: Human adenovirus type 36 enhances glucose uptake in diabetic and nondiabetic human skeletal muscle cells independent of insulin signalling. Diabetes 57: 1805-1813, 2008.

WEBER DJ, RUTALA WA, SAMSA GP, SANTIMAW JE, LEMON SM: Obesity as a predictor of poor antibody response to hepatitis B plasma vaccine. JAMA 254: 3187-3189, 1985.

WEBER DJ, RUTALA WA, SAMSA GP, BRADSHAW SE, LEMON SM: Impaired immunogenicity of hepatitis B plasma vaccine in obese persons. N Engl J Med 314: 1393, 1986. 
WEISBREN E, ROSEN H, BADER AM, LIPSITZ SR, ROGERS SO JR, ERIKSSON E: Percent body fat and prediction of surgical site infection. $J$ Am Coll Surg 210: 381-389, 2010.

WIGAND R, GELDERBLOM H, WADELL G: New human adenovirus (candidate adenovirus 36), a novel member of subgroup D. Arch Virol 64: 225-233, 1980.

WORLD HEALTH ORGANIZATION MEDIA CENTRE. Fact sheet N³11: Obesity and overweight. WHO Geneva, updated January 2015; http://www.who.int/mediacentre/factsheets/fs311/en/

YAMADA T, HARA K, KADOWAKI T: Association of adenovirus 36 infection with obesity and metabolic markers in humans: meta-analysis of observational studies. PLoS One 7: e42031, 2012.

ZAMRAZILOVÁ H, ALDHOON-HAINEROVÁ I, ATKINSON RL, DUŠÁTKOVÁ L, SEDLÁČKOVÁ B, LEE ZP, KUNEŠOVÁ M, HILL M, HAINER V: Adenovirus 36 infection: a role in dietary intake and response to inpatient weight management in girls. Int J Obes (Lond) in press 2015. 